\title{
Horizontal subsurface flow constructed wetlands for mitigation of ametryn-contaminated water
}

\author{
Alisson Carraro Borges ${ }^{1 *}$, Maria do Carmo Calijuri ${ }^{2}$, Antonio Teixeira de Matos $^{1}$ \\ and Maria Eliana Lopes Ribeiro de Queiroz ${ }^{3}$ \\ ${ }^{1}$ Department of Agricultural Engineering, Federal University of Viçosa, Av. Peter Henry Rolfs, s/n, CEP 36570-000, Viçosa, MG, Brazil \\ ${ }^{2}$ Department of Hydraulics and Sanitation, University of São Paulo, Av. Trabalhador São-carlense, 400, CEP 13566-590, São Carlos, SP, Brazil \\ ${ }^{3}$ Department of Chemistry, Federal University of Viçosa, Av. Peter Henry Rolfs, s/n, CEP 36570-000, Viçosa, MG, Brazil
}

\begin{abstract}
The feasibility of using constructed wetlands (CWs) for the mitigation of pesticide runoff has been studied in the last decade. However, a lack of related data was verified when subsurface flow constructed wetlands (SSF CWs) are considered for this purpose. In the present work, SSF CWs were submitted to continuous ametryn addition and evaluated during an 11-week period, with the aim of determining the feasibility of these systems for mitigation of contaminated water. Ametryn was not added to one $\mathrm{CW}$ cell in order to provide a control for the experiments. Monitoring of treatment performance was executed by standard water quality parameters, ametryn chromatography quantification and macrophyte (Typha latifolia L.) nutritional and agronomic property analysis. Results indicated that $39 \%$ of the total initially added amount of ametryn was removed, transferred or transformed. Herbicide metabolism and mineralisation were carried out by chemical and biological mechanisms. No statistic differences were observed in nutritional contents found in the $T$. latifolia crops of the CWs after the experimental period. Moreover, the biomass production (one valuable source of renewable energy) was equal to 3.3 tha $^{-1}$ (dry matter) in wetland cells. It was concluded that constructed wetland systems are capable of mitigating water contaminated with ametryn, acting as buffer filters between the emission sources and the downstream superficial water bodies.
\end{abstract}

Keywords: ametryn, constructed wetlands, macrophyte, pesticides, runoff

\section{Introduction}

In response to the increasing demands for agricultural productivity, it has been observed over the past 50 years that there has been a significant increase in the production and use of pesticides in general and particularly in herbicides (FAO, 2009). This increase in pesticide use may cause ecological and sanitary risks to the users of water bodies polluted with active ingredients from these agrochemicals.

Ametryn, whose IUPAC name is N-ethyl-N'-(1-methylethyl)-6-(methylthio)-1,3,5-triazine-2,4-diamine), is an important member of the triazines group and is used as a systemic herbicide mainly in the sugarcane, citrus, coffee and corn crops. Its decontrolled use, in addition to its physicochemical characteristics (Table 1), may result in the detection of potentially harmful concentrations in runoff waters from these crop lands.

Based on the proven purification capability of natural wetlands constructed wetland (CW) systems have been successfully used for the treatment of several types of point and nonpoint sources of pollution (IWA, 2000). Although used for wastewater treatment and nutrient removal, the use of CWs for the mitigation of contaminant pesticides is still considered incipient (Runes et al., 2003).

Over the past decade, studies have been performed with free water surface-flow (FWS) and open-pond wetlands

\footnotetext{
* To whom all correspondence should be addressed.

풍 +55 31 389918786; fax: +553138992735 ; e-mail: borges@ufv.bi

Received 22 December 2008; accepted in revised form 27 April 2009.
}

\begin{tabular}{|l|}
\hline \multicolumn{2}{|c|}{ TABLE 1 } \\
Physicochemical properties and characteristics of \\
ametryn (Adapted from USDA, 2006)
\end{tabular}

(Kadlec and Hey, 1994; Moore et al., 2000; Schulz et al., 2003; Rose et al., 2006). Few experiments have been reported in relation to subsurface flow (SSF) constructed wetlands (also known as reed-bed systems). McKinlay and Kasperek (1999) verified the reduction of atrazine concentration in CW cells with effluent re-circulation. Cheng et al. (2002) confirmed that the studied SSF CWs removed insecticides more efficiently than herbicides, considering that analysis was performed 4 months after pesticide application. George 


\begin{tabular}{|c|c|c|c|c|c|}
\hline \multicolumn{6}{|c|}{$\begin{array}{c}\text { TABLE } 2 \\
\text { Experimental results obtained in subsurface flow constructed wetlands treating pesticides }\end{array}$} \\
\hline Pesticide & $\begin{array}{c}\text { HRT } \\
\text { (d) }\end{array}$ & $\begin{array}{c}\text { Area } \\
\left(\mathrm{m}^{2}\right)\end{array}$ & $\begin{array}{c}\text { Initial conc. } \\
\left(g^{\prime} \cdot \mathrm{m}^{-3}\right)\end{array}$ & $\begin{array}{c}\text { Removal } \\
(\%)\end{array}$ & Reference \\
\hline Atrazine & n.r. & 1.2 & $6.0 \sim 7.0$ & $>99$ & McKinlay and Kasperek (1999) \\
\hline Dicamba & n.r. & 1.0 & $1.5 \mathrm{E}-03$ & 0 & Cheng et al. (2002) \\
\hline MCPA & n.r. & 1.0 & $2.8 \mathrm{E}-03$ & 36 & Cheng et al. (2002) \\
\hline Parathion & n.r. & 1.0 & $2.0 \mathrm{E}-03$ & 100 & Cheng et al. (2002) \\
\hline Metolachlor & $2.3 \sim 20$ & $5.9 \sim 11.8$ & n.r. & $82 \sim 90$ & Stearman et al. (2003) \\
\hline Simazine & $2.3 \sim 20$ & $5.9 \sim 11.8$ & n.r. & $77 \sim 83$ & Stearman et al. (2003) \\
\hline Metolachlor & $2.3 \sim 20$ & $5.9 \sim 11.8$ & 3.9 & $62 \sim 96$ & George et al. (2003) \\
\hline Simazine & $2.3 \sim 20$ & $5.9 \sim 11.8$ & 6.2 & $60 \sim 96$ & George et al. (2003) \\
\hline Lindane & $5 \sim 6$ & 55.0 & 2.5 & $>99$ & Matamoros et al. (2007) \\
\hline Simazine & $5 \sim 6$ & 55.0 & 2.5 & 20 & Matamoros et al. (2007) \\
\hline Alachlor & $5 \sim 6$ & 55.0 & 2.5 & 80 & Matamoros et al. (2007) \\
\hline
\end{tabular}

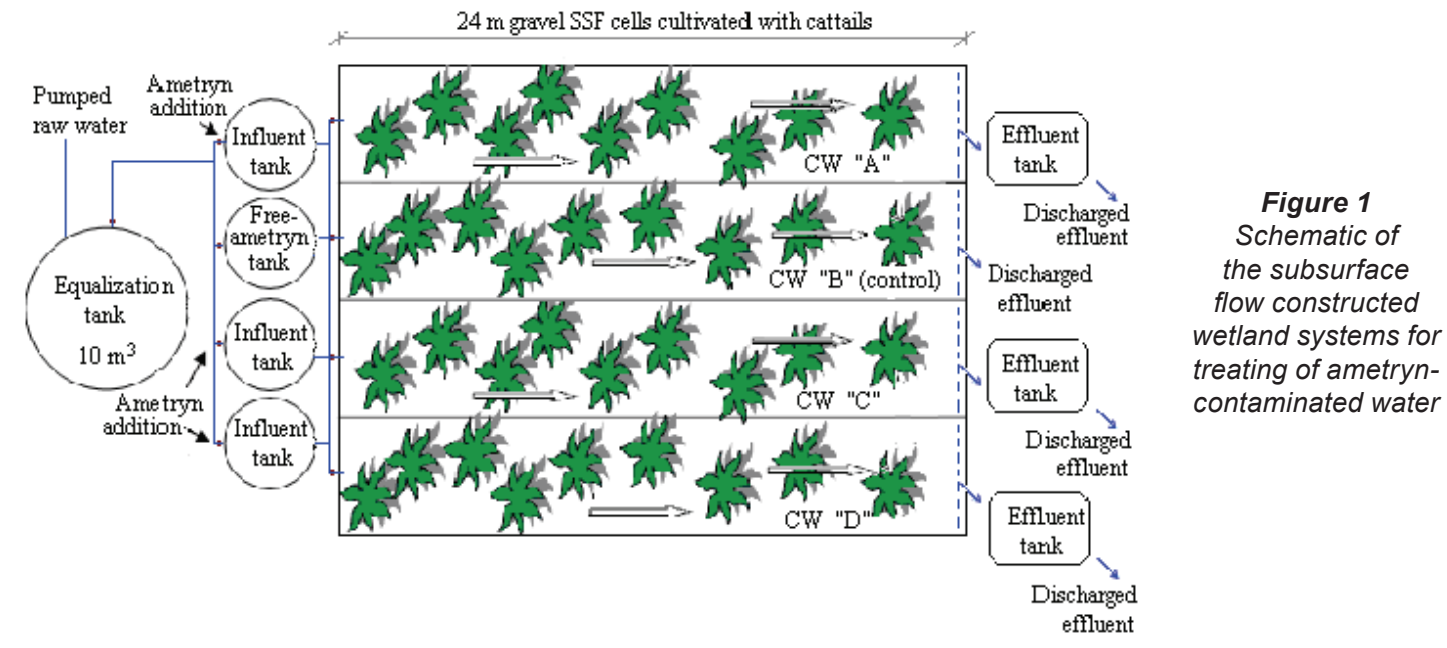

et al. (2003) and Stearman et al. (2003) proved the importance of the vegetative component (macrophytes) for simazine and metolachlor treatment.

According to Dordio et al. (2007), intensive action between plant rhizomes, microorganisms and matrix components can decrease pesticide concentration to levels that are safe for aquatic biota. However, Lin et al. (2008) recently observed that the increase of salinity in SSF CWs could inhibit the action of atrazine degrading microorganisms. Table 2 summarises the reported results when SSF CWs were used for the reduction of pesticide levels.

This research focused on the examination of ametryn in 4 subsurface flow constructed wetland cells operated under continuous loading of herbicide-contaminated water. The objectives of the research included the following:

- Determination of process efficiency based on the mass of ametryn removed in the CWs

- Study of the influence of operational factors on the CWs performance

- Verification of the nutritional conditions and agronomic performance of the macrophytes cultivated in the cells after the study period

\section{Materials and methods}

Four experimental CW cells were used in this study. CWs were constructed in parallel and walls were built with cement blocks. They were sealed with a watertight polyvinyl-chloride geo-membrane measuring $0.50 \mathrm{~mm}$ in thickness and presented overall dimensions of $0.35 \mathrm{~m}$ in height $\mathrm{x} 1.0 \mathrm{~m}$ in width $\mathrm{x} 24.0$ $m$ in length.

Fine gravel $(\mathrm{D} 60=7.0 \mathrm{~mm}$ and uniformity coefficient equal to 1.6) was used as a substrate for the macrophytes and Typha latifolia L. (common cattails) was grown in the CWs. Distribution and collection of the ametryn-contaminated water was monitored both upstream and downstream of each CW reservoir; this made it possible to calculate the daily water balance of the cells. A schematic presentation of the subsurface flow constructed wetland system is shown in Fig. 1.

Over a period of 11 weeks, ametryn-contaminated water was applied to $\mathrm{CW}$ Cells $\mathrm{A}, \mathrm{C}$ and $\mathrm{D}$, with varying bottom inclinations and total volumes: Cell $\mathrm{A}\left(0.5 \%\right.$ and $\left.5.70 \mathrm{~m}^{3}\right)$, Cell C $\left(1.0 \%\right.$ and $\left.4.40 \mathrm{~m}^{3}\right)$, Cell D $\left(1.5 \%\right.$ and $\left.3.30 \mathrm{~m}^{3}\right)$. Cell B $(1.0$ $\%$ and $4.40 \mathrm{~m}^{3}$ ) was used as the control, receiving raw water free of ametryn. The solution added to the systems $\left(1 \mathrm{~g} \cdot \mathrm{m}^{-3}\right.$ ametryn-nominal concentration) was prepared from the dilution of the Metrimex 500SC ${ }^{\text {TM }}$ (Sipcam Agro Co.) herbicide in raw water.

All systems were operated with the same hydraulic retention time (HRT). The applied flow rates corresponded to $0.77 \mathrm{~m}^{3} \cdot \mathrm{d}^{-1}$ for Cell A, $0.60 \mathrm{~m}^{3} \cdot \mathrm{d}^{-1}$ for Cell C and $0.45 \mathrm{~m}^{3} \cdot \mathrm{d}^{-1}$ for Cell D. Due to evapotranspiration observed in the cattail culture, part of the resident liquid in CWs was lost, therefore actual HRT values were superior to the $3.5 \mathrm{~d}$ initially proposed.

Samples were collected twice a week from the influent, at the $\mathrm{CW}$ midpoint and from the effluent of each of the Cells 


\begin{tabular}{|c|c|c|c|c|c|c|c|}
\hline \multicolumn{8}{|c|}{$\begin{array}{c}\text { TABLE } 3 \\
\begin{array}{l}\text { Results obtained for quality parameter concentrations in the equalisation tank } \\
\text { influent, mid-point }(12 \mathrm{~m}) \text { and effluent points of } \mathrm{CWs}\end{array}\end{array}$} \\
\hline \multirow[t]{2}{*}{ Parameter } & \multirow[t]{2}{*}{ Influent } & \multicolumn{2}{|c|}{ Cell A } & \multicolumn{2}{|c|}{ Cell C } & \multicolumn{2}{|c|}{ Cell D } \\
\hline & & $12 \mathrm{~m}$ & Effluent & $12 \mathrm{~m}$ & Effluent & $12 \mathrm{~m}$ & Effluent \\
\hline $\mathrm{COD}^{(\mathrm{a})}\left(\mathrm{g} \cdot \mathrm{m}^{-3}\right)$ & 19 & 32 & 40 & 40 & 22 & 36 & 27 \\
\hline Turbidity (uT) & 13 & 9 & 15 & 11 & 4 & 7 & 13 \\
\hline $\mathrm{EC}^{(\mathrm{b})}\left(\mu \mathrm{S} \cdot \mathrm{cm}^{-1}\right)$ & 55 & 74 & 105 & 65 & 98 & 64 & 94 \\
\hline $\mathrm{pH}$ & 7.0 & 6.2 & 6.7 & 6.4 & 6.8 & 6.6 & 6.8 \\
\hline $\mathrm{TA}^{(\mathrm{c})}\left(\mathrm{g} \cdot \mathrm{m}^{-3}\right)$ & 21 & 32 & 56 & 29 & 48 & 27 & 49 \\
\hline
\end{tabular}

A, C and D, for laboratory analysis. At the end of the studied period, cuts were made in the vegetative sections (leaf tissues) of all cells for nutritional analysis of the used macrophytes. Samples of the support material were analysed for organic matter. The samplings performed at the end of the study were done in portions of $2 \mathrm{~m}^{2}$ located at the beginning, middle and final portions of each CW (A, B, C and D). These procedures were executed in order to evaluate the possible absorption of pesticides in the organic material present in the $\mathrm{CW}$.

After extraction in the liquid phase with acetonitrile and ethyl acetate, according toVieira et al. (2007), the herbicide was quantified with a gas chromatograph Shimadzu GC-17A (Shimadzu Co.) operating with Class-CR10 software, and equipped with a flame ionisation detector (FID) at $300^{\circ} \mathrm{C}$ and BP-5 column (J\&W Scientific). For ametryn quantification, peak areas were observed and concentrations determined using the standard curve prepared by the addition of known standard concentrations. For the blank sample, no peak was observed at the retention time for analyte. The analytical standard was supplied by Sipcam Agro Co. $(95.9 \% \mathrm{~m} / \mathrm{m})$. Chemical oxygen demand, turbidity, conductivity, temperature, total solids and alkalinity were monitored according to Standard Methods (2005), methods 5220, 2130, 2510, 2550, 2540 and 2320B. Nitrogen, phosphorus, potassium, calcium and sulphur concentrations in the leaf tissues were also quantified. Organic matter in the gravel beds was quantified by igniting the samples under controlled conditions.

The possible significant differences among the data $(\alpha=$ 0.05 ) were observed with the use of Lillierfors and Bartlett tests (for normality and homogeneity verification) followed by application of statistical tests, when pertinent: Parametric tests were utilised when equality of variance from the Bartlet test was $p \geq 0.05$ and non-parametric tests were used when the equality of variance was $\mathrm{p} \leq 0.05$.

\section{Results and discussion}

Calculations necessary to obtain the water balance in the CWs were made based on local weather station data and daily gauging of the effluent volumes in the downstream tanks. The mean value for the culture evapotranspiration (ETc) in CWs was $5.7 \mathrm{~mm}$, while mean values of ETo (according to Hargreaves' method) and ET (Class A) were $4.6 \mathrm{~mm}$ and $3.7 \mathrm{~mm}$, respectively. The percentage of water lost in relation to volume of influent added to the CWs was about $12 \%$ to $24 \%$, being lower than the values observed in arid areas or in CW cells operating at higher temperatures. However, these loss estimates are comparable to those made by Brasil et al. (2007), who reported percentage volume decreases of between $11 \%$ and $27 \%$.

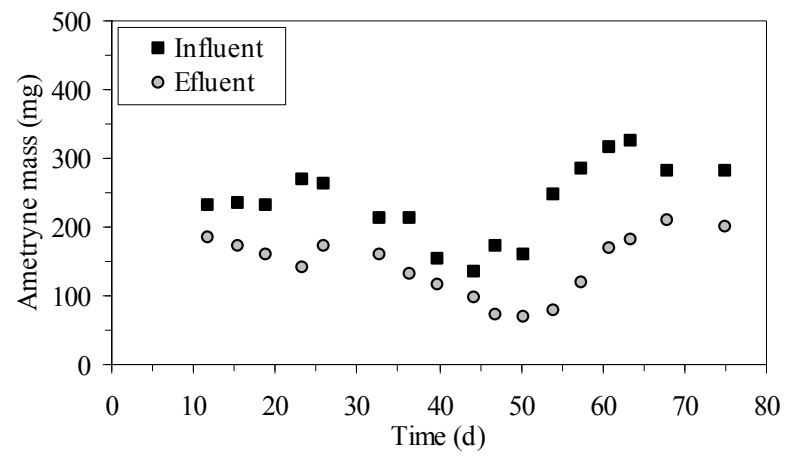

Figure 2

Ametryn mass reduction in SSF constructed wetland systems

Reduction of the mean flow rates due to macrophyte evapotranspiration provided a rapid modification in the mean HRT in CWs and an increase in the solutes concentration in the effluent, as observed in Table 3. Several researchers including Green (2006) and Mara (2006) also discuss such observations. Evaluation of herbicide removal efficiency was made by quantifying mass loads applied and recovered.

For comparison of the cells, samples taken over the entire experimental period were considered. The effluent concentrations did not present significant difference $(\alpha=0.05)$ when the Kruskal-Wallis test was applied. Therefore, average values of the cells were used for comparison since the number of valid analyses was reduced (between 23 and 26) due to occasional contamination during sampling.

Figure 2 illustrates the ametryn contents based on the computation of moving averages ( 2 weeks) of the mass loads in the 3 contaminated CW cells. The average influent contents were significantly different from the average effluent contents.

Operating with a HRT of $3.8 \mathrm{~d}$, the systems removed/ transformed approximately $39 \%$ of the added ametryn. When compared to previously published data, these values are considered low. However, in the present work, ametryn was applied continually and therefore greater quantities were administered with higher superficial loading rates $\left[\mathrm{M} \cdot \mathrm{L}^{-2} \cdot \mathrm{T}^{-1}\right]$.

In a similar experiment, but with a vertical flow pathway, Cheng et al. (2002) observed that herbicides are removed at slower rates when compared to insecticides. The authors verified that the insecticide parathion was not detected at the exit of the CWs. Observed removal of dicamba and MCPA (herbicides) were $0 \%$ and $36 \%$, respectively.

The non-recovered fraction in the effluent of CWs was assumed to be transformed and stored by biotic and abiotic processes in the constructed wetland systems. The added 


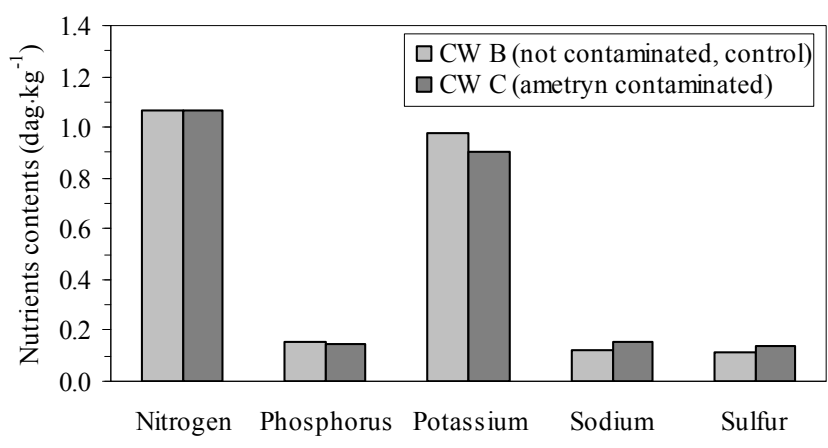

Figure 3

Average nutrient contents in leaf tissues of cattails cultivated in $C W$ ' $B$ ' and $C W$ ' $C$ '

herbicide is slightly volatile $\left(\mathrm{P}<1.33 \mathrm{mPa}\right.$ and $\mathrm{K}_{\mathrm{H}}<0.1 \mathrm{~Pa}$ $\left.\mathrm{m}^{3} \cdot \mathrm{mol}^{-1}\right)$, thus the implementation of sub-superficial type flow reduces the likelihood of any significant photodegradation activity.

Ametryn has a high water solubility of $204 \mathrm{~g} \cdot \mathrm{m}^{-3}$. Highly soluble pesticides tend to present reduced $\mathrm{K}_{\mathrm{OC}}$ and $\mathrm{K}_{\mathrm{OW}}$ values, promoting absorption and translocation processes in the plant.

These properties account for the low affinity of ametryn for soil colloids, making the herbicide potentially leachable. Moore et al. (2000), studying the mitigation effects of atrazine (the world's most used triazine herbicide), did not detect pesticide concentrations in the sediment of the used wetlands. Considering that when concentrations of atrazine are present in both sediment and water phases, phytotoxicity was generally determined by the concentration in the water, and researchers then opted for analysis of the aqueous phase. In the present study, the presence/absence of organic matter (OM) in the gravel beds was investigated. The fact the most inclined $\mathrm{CW}$ presented a greater $\mathrm{OM} /$ gravel ratio did not imply greater efficiency due to sorption. Therefore, in agreement with data reported by Matamoros et al. (2007), sorption by gravel could be neglected due to the biodegradation, plant uptake and desorption processes occurring in CW cells.

The HRT in the CW cells provided greater influence compared to other operational parameters. Stearman et al. (2003) observed that SSF CWs operating with HRT of $5.1 \mathrm{~d}$ were more efficient than systems with HRT of $2.3 \mathrm{~d}$. The same observation was made in surface-flow CWs for atrazine treatment (Moore et al., 2000; Runes et al., 2003). In relation to the applied flow rates and the different bottom inclinations, it was suggested that the absence of apparent discrepancies was due to factors including scale problems and magnitude of the observed pesticide values (reduced and difficult detection levels).

The nutritional performance of the plants was analyzed based on the yield of dry matter and by analysis of macrophyte nutrients in each treatment. Figure 3 shows the mean values regarding nutrient levels observed in the $\mathrm{CW}$ ' $\mathrm{C}$ ', subjected to the pesticide and in the $\mathrm{CW}$ control 'B' (both $\mathrm{CWs}$ had the same bottom slopes of $1.0 \%$ ). Comparing the averages of all $\mathrm{CW}$ cells (A, B, C and D), the nutritional analysis accomplished at the end of the studied period did not present significant statistical difference $(\alpha=0.05)$.

Although the function of macrophytes is sometimes contested, they play an important role in absorption of ametryn. During implantation of vegetation, macrophytes provide a unique environment for the survival of microorganisms in sub superficial sites of CWs. In the present study, harmful effects were not observed in the vegetative portion (leaf tissues) of the plants when a nutritional analysis was performed and compared with the control CW. Recently, some authors including Moore et al. (2006), verified that vegetated cells were more efficient for methyl-parathion mitigation; moreover, the possible energy use of the macrophyte biomass is also a factor to be considered.

In microbial degradation, mentioned by McKinlay and Kasperek (1999) as the main process in atrazine degradation in CWs, it is known that this process is accelerated in vegetated $\mathrm{CW}$ cells due to the biofilm formed in the sub superficial area and these microbes depend on availability of nutrients and the adaptation capacity of the species to the introduced compound. More studies on ametryn transformation are required since there are few studies concerning this pesticide when compared with other herbicides, such as atrazine for instance.

\section{Conclusions}

As observed in the field study using treatment systems with applied water losses, the water balance must be calculated since solutes are more concentrated in the effluent. It was estimated that $12 \%$ to $24 \%$ of water was lost.

The amount of ametryn detected in the $\mathrm{CW}$ effluents was estimated to be $61 \%$ of the initially added amount. The remaining fraction was transformed and retained by biotic and abiotic processes in the CWs. It was verified that CWs with different slope inclinations did not present significant performance differences. Increase of the effective HRT is an operational strategy to be considered, allowing longer contact times between the herbicide and the root system with the adhered microbial population.

Macrophytes play an important role in this process. Besides the absorption of the herbicide composition, the implantation of the vegetative portion provides a unique environment for the multiplication of microorganisms in sub-superficial sites of CWs. In the present study, harmful effects were not observed in the vegetative part of the plants when nutritional analyses were performed and compared with the control cell.

Constructed wetland systems are capable of retaining and transforming pesticides, acting as filters between the emission source and the superficial water bodies. Environmental management plans elaborated by governmental organisations with the support of landowners, could use these CW systems in the mitigation of the environmental pollution. However, there is an observed need for more studies on pesticide removal processes in CWs as well as better control of emission sources of these diffuse pollutants.

\section{Acknowledgements}

Constructive comments by the anonymous reviewers are gratefully acknowledged. The authors also thank Mr Evan M Visser for the revision of this paper.

\section{References}

BRASIL MS, MATOS AT, SILVA CM, CECON PR and SOARES AA (2007) Modeling of pollution removal in constructed wetlands with horizontal subsurface flow. Agrartechnische Forschung 13 (2) 48-56.

CHENG S, VIDAKOVIC-CIFREK Ž, GROSSE W and KARRENBROCK F (2002) Xenobiotics removal from polluted water by a multifunctional constructed wetland. Chemosphere 48 (4) 415-418.

DORDIO AV, TEIMÃO J, RAMALHO I, CARVALHO AJP and CANDEIAS AJE (2007) Selection of a support matrix for the 
removal of some phenoxyacetic compounds in constructed wetlands systems. Sci. Total Environ. 380 (1-3) 237-246.

FAO (2008) Food and Agriculture Organization FAOSTAT. FAO, Rome http://faostat.fao.org

GEORGE D, STEARMAN GK, CARLSON K and LANSFORD S (2003) Simazine and metolachlor removal by subsurface flow constructed wetlands. Water Environ. Res. 75 (2) 101-112.

GREEN M (2006) Response to comment on 'Minimizing land requirement and evaporation in small wastewater treatment systems' Ecol. Eng. 28 (2) 182-182.

INTERNATIONAL WATER ASSOCIATION (2000) Constructed Wetlands for Pollution Control: Process, Performance, Design and Operation. IWA, London. $156 \mathrm{pp}$.

KADLEC RH and HEY DL (1994) Constructed wetlands for river water quality improvement Water Sci. Technol. 29 (4) 159-168.

LIN T, WEN Y, JIANG L, LI J, YANG S and ZHOU Q (2008) Study of atrazine degradation in subsurface flow constructed wetland under different salinity Chemosphere 72 (1) 122-128.

MARA DD (2006) Comment on 'Minimizing land requirement and evaporation in small wastewater treatment systems' Ecol. Eng. 28 (2) 181-181.

MATAMOROS V, PUIGAGUT J, GARCIA J and BAYONA JM (2007) Behavior of selected priority organic pollutants in horizontal subsurface flow constructed wetlands: A preliminary screening. Chemosphere 69 (9) 1374-1380.

McKINLAY RG and KASPEREK K (1999) Observations on decontamination of herbicide-polluted water by marsh plant systems. Water Res. 33 (2) 505-511.

MOORE MT, RODGERS JH, COOPER CM and SMITH S (2000) Constructed wetlands for mitigation of atrazine-associated agricul- tural runoff. Environ. Pollut. 110 (3) 393-399.

MOORE MT, BENNETT ER, COOPER CM, SMITH S, FARRIS JL, DROUILLARD KG and SCHULZ R (2006) Influence of vegetation in mitigation of methyl parathion runoff. Environ. Pollut. 142 (2) 288-294.

ROSE MT, SANCHEZ-BAYO F, CROSSAN AN and KENNEDY IR (2006) Pesticide removal from cotton farm tailwater by a pilotscale ponded wetland. Chemosphere 63 (11) 1849-1858.

RUNES HB, JENKINS JJ, MOORE JA, BOTTOMLEY PJ and WILSON BD (2003) Treatment of atrazine in nursery irrigation runoff by a constructed wetland. Water Res. 37 (3) 539-550.

SCHULZ R, HAHN C, BENNETT ER, DABROWSKI JM, THIERE $\mathrm{G}$ and PEALL SKC (2003) Fate and effects of azinphos-methyl in a flow-through wetland in south Africa. Environ.Sci. Technol. 37 (10) 2139-2144.

STANDARD METHODS (2005) Standard Methods for the Examination of Water and Wastewater (21 $1^{\text {st }}$ edn.) American Public Health Association/American Water Works Association/Water Environment Federation, Washington DC, USA.

STEARMAN GK, GEORGE DB, CARLSON K and LANSFORD S (2003) Pesticide removal from container nursery runoff in constructed wetland cells. J. Environ. Qual. 32 (4) 1548-1556.

US DEPARTMENT OF AGRICULTURE (2006) ARS Pesticide Properties Database. http://www.ars.usda.gov/services/docs htm?docid=14199 (Accessed 15 December 2008).

VIEIRA HP, NEVES, AA and QUEIROZ, MELR (2007) Optimization and validation of liquid-liquid extraction with the low temperature partition technique (LLE-LTP) for pyrethroids in water and GC analysis (in Portuguese). Quím. Nova 30 (3) 535-540. 
Available on website http://www.wrc.org.za ISSN 0378-4738 = Water SA Vol. 35 No. 4 July 2009

ISSN 1816-7950 = Water SA (on-line) 